\title{
Assessment of sedimentation rates in the Way Seputih Watershed Area
}

\author{
Hendri Setiawan*, Iwan Rudiarto, and Jafron Wasiq Hidayat \\ Master Program of Environmental Sciences, School of Post-Graduate, Diponegoro University, \\ Semarang - Indonesia
}

\begin{abstract}
Way Seputih watershed is one of the important watersheds located in Central Lampung Regency and is a source of waters both agriculture and industry. The occurrence of floods that occur during the rainy season is due to reduced forest cover that is converted to agricultural land and settlements. In the Way Seputih River many sand mining activities will have implications for the sedimentation process at the downstream of the Way Seputih River. The purpose of this study is to identify the effects of sedimentation using the SWAT model. To find out changes in land use/cover using the SWAT SUFI-2 analysis. Calibration and Validation are carried out to obtain the accuracy of the model. Model accuracy is measured using Nash Sutcliffe Efficiency values (0.58 and 0.62 ), and coefficient of determination (R2) ( 0.69 and 0.62). This condition is influenced by the runoff curve number (CN2.mgt) factor. Sediment prediction averaged 117,027 tons/ha in each sub-watershed. Good management is needed to reduce the rate of sedimentation.
\end{abstract}

Keywords : Way Seputih, land use/cover, sediment, SWAT

\section{Introduction}

Increased development, resettlement, and reduced forest cause land use/cover changes [1] which have an impact on the balance of nature. Fulfilling human needs for development, land use tends to increase in its usefulness and potential [2]. Land use/cover changes can affect the functioning of ecosystems because the environmental carrying capacity decreases.

Land use/cover changes are hydrological indicators that occur naturally or artificially. Problems in watersheds generally stem from irresponsible land-use change. Floodplains and drought are the implications of the reduced ability of the soil to retain runoff water in the form of erosion. Erosion occurs due to high rainfall that will affect the increase in sedimentation intensity. So it is important to analyze land use/cover of sediment rates. [3] States that watershed damage can reduce the watersheds ability to store water, increase soil erosion and sedimentation, and increase the intensity of annual flooding. Natural damage will occur if erosion and sedimentation are spread continuously.

\footnotetext{
*Corresponding author: hendristw@gmail.com
} 
The Way Seputih Watershed is one of the management priorities by Lampung Province because the river always experiences flooding and forest land is decreasing [4]. Changes in upstream forest land in the period 2000-2015 were $15.06 \%$. The change was converted to plantation land and settlement. As a result of land conversion, increasing the surface runoff coefficient from 0.17 to 0.23 [5] will increase the intensity of erosion. According to Law No. 37/2012, the way to maintain the carrying capacity of the environment is by implementing soil and water conservation. Also, the hydrological model might be an alternative for watershed management because it can be applied to the watershed.

SWAT (Soil and Water Assessment Tool) is a semi-distribution hydrological model for the watershed scale developed by Dr. Jeff Arnold from the USDA. This model can simulate a long-term hydrological response [6]. Much research has been done to improve the SWAT model in the tropics. Some studies have analyzed the impact of land use/cover on sediment yield. [7] Several models can be used to analyze the impact of land use/cover in the hydrological process, namely the time-trend analysis method, paired catchment, and hydrological modeling. Among the hydrological models, the SWAT hydrological model is often used to analyze the impact of land use/cover on quality, quantity and water continuity.

The purpose of this study was to analyze the impact of land use/cover changes on the erosion process. The SWAT model is used to identify land use/cover changes and simulate erosion results in catchments.

\section{Materials and Methods}

\subsection{Study Area and Data}

Way Seputih watershed is mostly located in Central Lampung Regency, in Lampung Province. The watershed has an area of $7550 \mathrm{~km}^{2}$ (Figure 1). The main river is the Way Seputih River which has a length of $965 \mathrm{~km}$. This watershed has the characteristics of a tropical climate and has a dominant land use/cover, namely agricultural land (maize, cassava, soybeans, peanuts, etc.), agricultural land mixed with shrubs, secondary forests in the upper watershed, and settlements in the middle to downstream. 


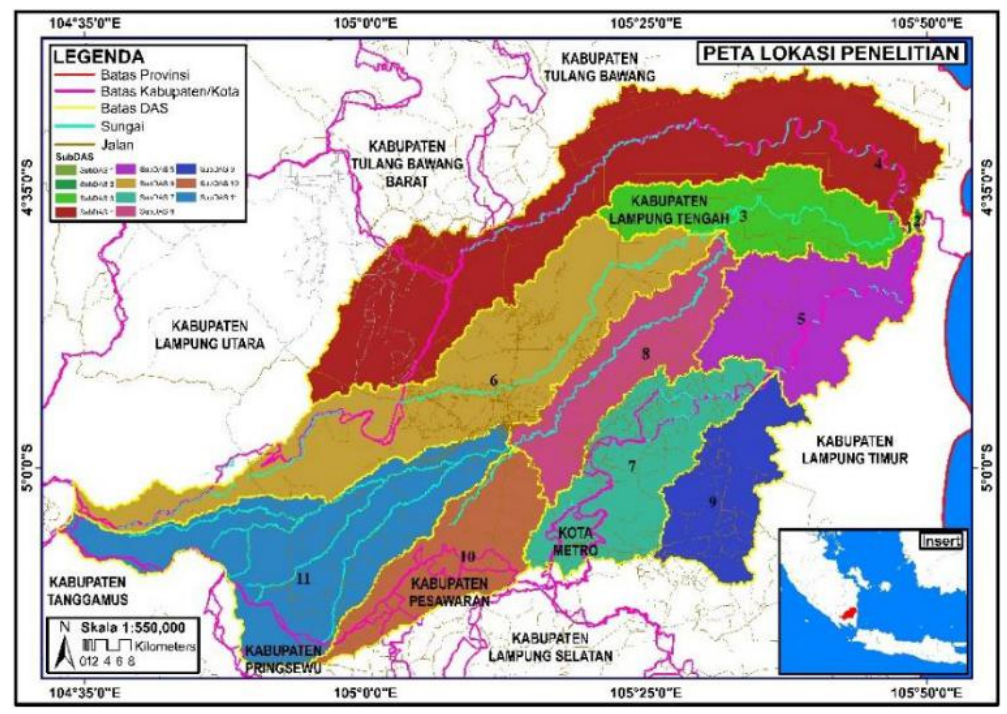

Fig. 1. Location of the Way Seputih Watershed research

The data used are spatial and non-spatial. Spatial data information is DEM (Digital Elevation Model), land use/cover, and soil type. DEM was obtained from the Geospatial Information Agency of Indonesia. Land use/cover maps, and maps of soil types obtained from the Way Seputih Way Sekampung Watershed Management and Watershed Management Center. Land use/cover map consists of 2010, 2015. The two maps are used to see changes that have occurred in the last 6 years. The use of the two maps is used separately, namely the 2010 map for calibration and 2015 for validation.

Non-spatial data information consists of climatological data, river discharge. Climatology data obtained from the Meteorology Climatology and Geophysics Agency Masgar Lampung include rainfall, temperature, humidity, wind speed, and duration of sun exposure in the period 2010-2015. Information on river discharge data was obtained from the Mesuji-Sekampung Watershed Agency in the 2010-2015 period. Climatology data is used for SWAT database input, while river discharge data is used for calibration, validation, and model simulation processes.

\subsection{Methodology}

\subsubsection{SWAT Model}

SWAT is a semi-distribution hydrological model for the physical scale of the watershed which is used to simulate hydrological variables daily or can also be done on a monthly or annual basis. This model was developed by the United States Department of Agriculture to simulate land management models for sediment yield in watersheds. This model has a high level of efficiency in simulating in the long run. This model has important input data in the simulation process namely rainfall, temperature, DEM, land use/cover maps [8].

This model has a framework that is based on the hydrological cycle in parts of land and water. The soil section manages the flow of water, sediment, and nutrients in each subwatershed. This model also regulates sediment and water paths to the observation outlet [9]. SWAT simulates the hydrological cycle using equation (1). The equation can read SWAT 
data input in producing simulations for a certain period. The input file is the climatology data obtained as a SWAT database.

$$
S W t=S W o+\sum{ }^{t}=1(R d a y-Q s u r f-E a-w s e e p-Q g w) i
$$

where $\mathrm{SW}_{\mathrm{t}}$ is the final groundwater content $\left(\mathrm{mm} \mathrm{H}_{2} \mathrm{O}\right), \mathrm{SW}_{\mathrm{o}}$ is the initial groundwater content on the $\mathrm{i}$-day $\left(\mathrm{mm} \mathrm{H}_{2} \mathrm{O}\right), \mathrm{t}$ is the time (day), $\mathrm{R}_{\text {day }}$ is the amount of rain on the $\mathrm{i}$-day $\left(\mathrm{mm} \mathrm{H} \mathrm{H}_{2} \mathrm{O}\right), \mathrm{E}_{\mathrm{a}}$ is the amount of evapotranspiration on the i-day $\left(\mathrm{mm} \mathrm{H}_{2} \mathrm{O}\right), \mathrm{W}_{\text {seep }}$ is the amount of water entering the vadose zone of the soil profile (see page) on the i-day (mm $\mathrm{H}_{2} \mathrm{O}$ ), $\mathrm{Qgw}_{\mathrm{gw}}$ is the amount of underground water flow (base flow/groundwater/return flow) on the i-day $\left(\mathrm{mm} \mathrm{H}_{2} \mathrm{O}\right)[10]$.

SWAT can carry out hydrological simulations on different land uses / covers with different climatic conditions. SWAT has been widely used for hydrological simulation research focusing on land use/cover conditions and climate change [11]. This model is widely used because of its ability to represent the physical condition of an area with water movement, with additional software such as SWAT CUP used for calibration and model validation.

\subsubsection{Data Analysis}

SWAT consists of three consecutive sub-models: watershed delineation, manufacturing HRU (Hydrologic Response Unit), and running SWAT [12]. Each model requires a separate dataset and model input parameters, which can be considered as sources of uncertainty in SWAT, watershed can be divided into Sub-Watersheds, which are then divided into Hydrologic Response Units (HRU). HRU is made by combining all areas that have the same combination of land use, soil type, and slope in a sub-watershed [13]. The SWAT model is calibrated and validated against the flow (water) conditions. This analysis compares the relative changes in the simulation because the hydrological model can simulate the actual water cycle [14]. The SWAT analysis process can be seen in Figure 2.

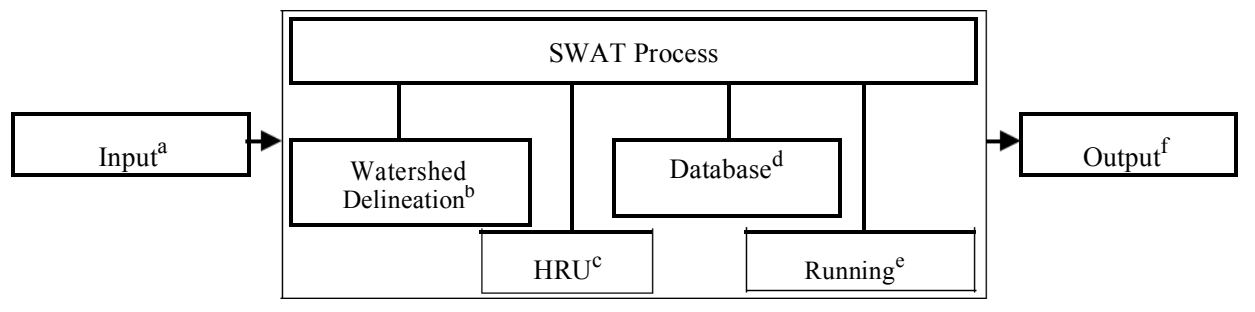

Fig. 2. SWAT analysis system

where (a) the input stages of the SWAT process become an important component in generating multiple files or outputs. The inputted data will be processed based on their respective functions both interpretation, overlay, and mathematical calculations. Data inputted in the SWAT analysis is in the form of DEM (Digital Elevation Model), land use maps, soil type maps, and climatological data. (b) this process processes the Digital Elevation Model data into study location boundaries according to the observation outlet. (c) this stage is processing or overlaying land use map data, soil type maps into small area units that have a Hydrologic Response Unit based on the level of slope used. (d) this process reads climatology data in the form of temperature, humidity, solar radiation, wind speed which will be used for the running process at the final stage. (e) this stage is an important process because all the small stages in it will be processed or run to produce an output from this analysis. (f) The output of this SWAT analysis has 76 files based on HRU. One of the files that will be used for SWAT-Cup analysis is flowrate. 
SWAT-Cup is a program developed for the process of calibration, validation, and uncertainty analysis of SWAT and is used to optimize the parameters of the SWAT model [15] in the SWAT analysis process. SUFI-2 was chosen for the calibration, validation, and uncertainty analysis of SWAT because it is quite efficient for models that have a certain period [16]. SWAT-CUP is a tool developed by [15] which has several algorithms (GLUE, MCMC, SUFI-2, and Parasol) to validate the model. This enables sensitivity analysis, calibration, validation, and uncertainty analysis of various hydrological parameters [17]. This study follows [18] with a statistical test of the model namely NSE and $\mathrm{R}^{2}$. NSE is a statistic that is often used to compare observational data with models [19]. The SWAT-Cup analysis process can be seen in Figure 3.

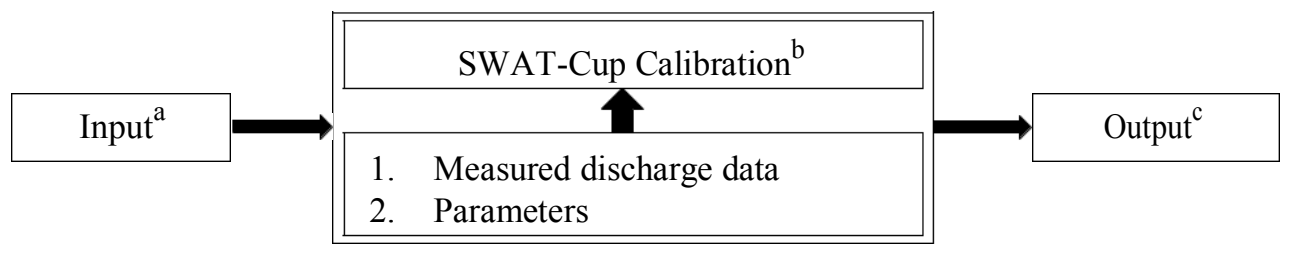

Fig. 3. SWAT CUP analysis system

where (a) is a SWAT calibration input derived from the results of running the previous SWAT Analysis. This step will read the output file in the "TxtInOut" folder. (b) the calibration process uses river flow data. The use of river flow data will be calibrated by reading the predicted flow from the previous SWAT model. The calibration process is influenced by some of the best parameters of more than 500 parameters contained in the SWAT system. (c) the output of the calibration process is in the form of a graph of suitability between predicted discharge and measured discharge. These results are supported by several statistical tests that come out of the SWAT-Cup system. The value of the best parameter will be used as the next scenario simulation.

\section{Result and Discussion}

\subsection{Watershed Characteristics}

The Way Seputih watershed as the study is $7007.66 \mathrm{Km}^{2}$. The formation of the study area is based on the DEM (Digital Elevation Model) map. Each Sub-watershed has its characteristics that affect water flow and sediment yield. The Way Seputih watershed has a height category ranging from $-3 \mathrm{~m}$ to $1179 \mathrm{~m}$ upstream (Figure 4). 


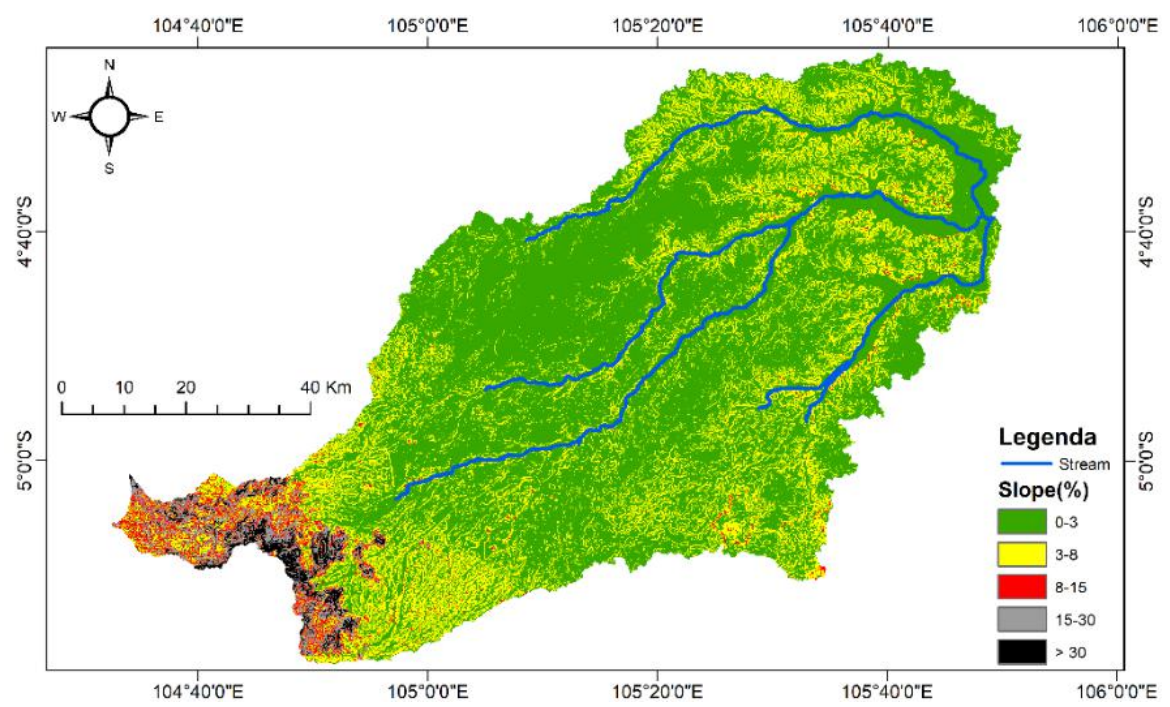

Fig. 4. Slope classes of Way Seputih Watershed

The study sites generally have areas that do not vary in height (relatively flat). Only the upstream part of the watershed has a high area. Therefore, most of the study areas have more or less the same characteristics. The study area is divided into 5 height classes namely $(0-3) \%,(3-8) \%,(8-15) \%,(15-30) \%$, and (>30)\% (Table 1).

Table 1. Slope classes of Way Seputih Watershed

\begin{tabular}{|c|c|c|c|}
\hline No & Slope (\%) & Area $\left(\mathrm{Km}^{2}\right)$ & $\%$ \\
\hline 1 & $0-3$ & 5007,53 & 71,46 \\
\hline 2 & $3-8$ & 1689,39 & 24,11 \\
\hline 3 & $8-15$ & 138,56 & 1,98 \\
\hline 4 & $15-30$ & 145,71 & 2,08 \\
\hline 5 & $>30$ & 26,04 & 0,37 \\
\hline & Total & 7007,66 & 100 \\
\hline
\end{tabular}

A watershed has different soil type characteristics. The land is an important component in watershed management. The dominant soil type in the study area is Podsolik Merkun. This type of land is often found because in the study area has a predominantly land use for agriculture and plantation. This land is suitable for farming. Distribution of this type of soil is found in the Sumatra region, especially in Lampung.

An important part of the watershed hydrological cycle is land use/cover. Land use/cover is a factor that causes watersheds to save water reserves and inhibit surface runoff. This study uses LULC 2010 and LULC 2015 to analyze changes or land-use changes that occur (Figure 5). Changes in land use/cover in the Way Seputih watershed have not been too massive in the past 6 years (Table 2). However, it should be noted that changes in residential land $\left(+1,68 \mathrm{Km}^{2}\right)$ are increasing. Based on field surveys, development is generally not far from the river flow. This will lead to high erosion and sedimentation potential. It should be noted that the decline of dryland farming land into settlements has become a trend lately. Even the paddy fields also turn into housing. Therefore, it is important to know the changes in LULC that occur to find out how it affects soil erosion. 


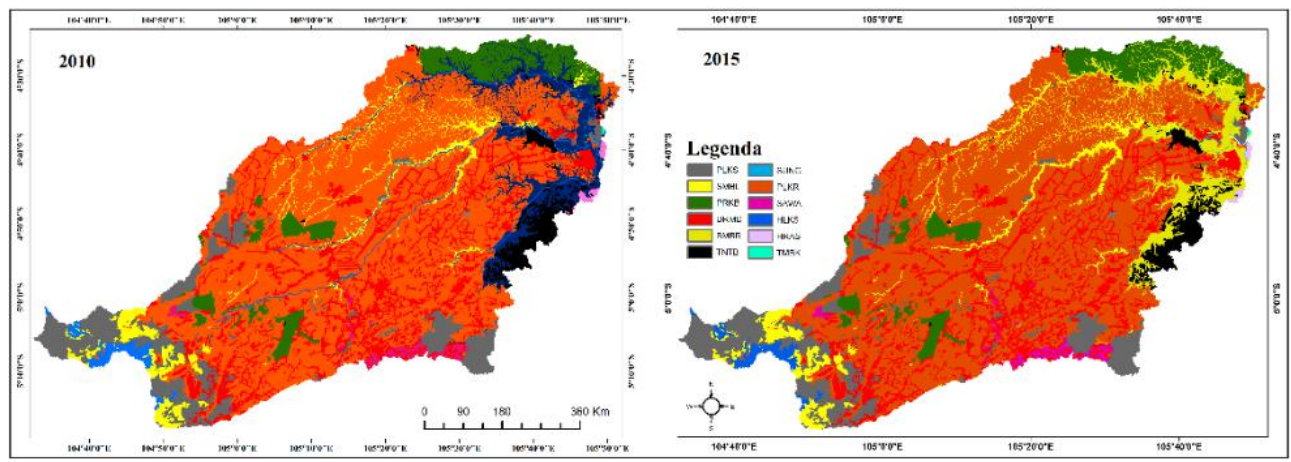

Fig. 5. Land use/cover of the Way Seputih Watershed

Table 2. Land use/cover change

\begin{tabular}{|c|l|r|r|c|}
\hline \multirow{2}{*}{ No. LULC Type } & \multicolumn{2}{c|}{ Area $\left(\mathrm{Km}^{2}\right)$} & $\begin{array}{c}\text { Land } \\
\text { conversion }\end{array}$ \\
\cline { 3 - 5 } & & 2010 & 2015 & area $\left(\mathrm{Km}^{2}\right)$ \\
\hline 1 & Dry Mixed Farming with Shrubs & 595,07 & 595,40 & $+0,33$ \\
\hline 2 & Pond & 1,49 & 1,47 & $-0,02$ \\
\hline 3 & Swamp Shrub & 460,86 & 462,16 & $+1,3$ \\
\hline 4 & Shrubs & 188,81 & 188,45 & $-0,36$ \\
\hline 5 & & & & \\
\hline 6 & Settlement & 4222,67 & 4221,42 & $-1,25$ \\
\hline 7 & Plantation & 1008,83 & 1010,51 & $+1,68$ \\
\hline 8 & Open Land & 358,49 & 358,66 & $+0,17$ \\
\hline
\end{tabular}

\subsection{Analysis of flow sensitivity}

The use of SWAT parameters and analysis functions to make the condition of the model as it was originally. However, these parameters must pass the calibration and validation process first. Not all parameters used are influential, only parameters that are sensitive to observational variables are used. The calibration and validation process uses the Way Seputih river flow, respectively 2010-2012 and 2013-2015. The observation point or outlet is based on the most downstream part of the river approaching the estuary. The parameters used in this analysis are 6 parameters (Table 3).

The use of parameters for calibration will automatically use the SWAT CUP software. The software will read the most sensitive parameters so that it will affect the water flow model. After the water flow shows values close to AWLR, parameter values will be used for validation in different years. This process is mutually sustainable by taking into account the parameters used.

\subsection{Flow Calibration and Validation}

The SWAT simulation produces data that cannot be used yet, so it must perform the data calibration process using the SWAT CUP software. The calibrated data is the monthly river flow discharge data by comparing it with the monthly observational discharge of the Way Seputih River in 2010-2012. The calibration and validation graph shows a curve similar to AWLR (Figure 6). This shows that this model can be used to represent conditions in the field. These curves are supported by existing statistical analysis. 
The calibration process is carried out by changing the values of the parameters (Table 3 ) related to the research topic. In this calibration, the best simulation in the $17^{\text {th }}$ simulation out of 400 simulations is considered to be the closest simulation discharge value to the observed discharge value. From the best simulation, the NS (Nash-Sutcliffe) coefficient value is $0.58, \mathrm{R}^{2}$ value is 0.69 .

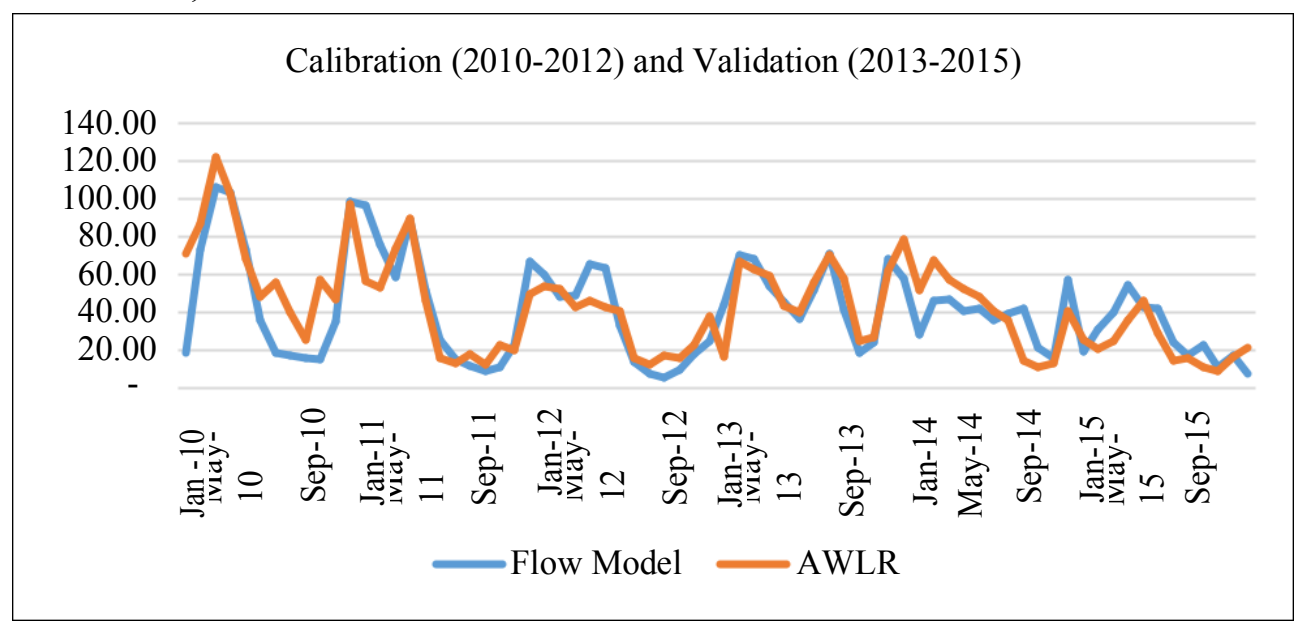

Fig. 6. Stream flow calibration (2010-2012) and validation (2013-2015)

Table 3. Analysis parameter

\begin{tabular}{|c|c|c|c|c|}
\hline No & Parameters & Definisi & Range & $\begin{array}{l}\text { Calibration } \\
\text { Value } \\
\end{array}$ \\
\hline 1 & CN2 (.mgt) & $\begin{array}{l}\text { Runoff Curve } \\
\text { Number }\end{array}$ & $94,982590-96,618271$ & 95,782028 \\
\hline 2 & $\begin{array}{l}\text { ALPHA_BF } \\
(. g w)\end{array}$ & $\begin{array}{l}\text { Groundwater Flow } \\
\text { Factor (days) }\end{array}$ & $0,022551-0,035091$ & 0,031031 \\
\hline 3 & $\begin{array}{l}\mathrm{SOL} \_\mathrm{AWC} \\
\text { (.sol) }\end{array}$ & $\begin{array}{l}\text { Soil Capacity Holds } \\
\text { Water }(\mathrm{mm} / \mathrm{mm})\end{array}$ & $0,148899-0,401027$ & 0,280951 \\
\hline 4 & CH_N2 (.rte) & $\begin{array}{l}\text { Manning's Constant } \\
\text { Surface River }\end{array}$ & $0,058121-0,262141$ & 0,097650 \\
\hline 5 & $\begin{array}{l}\text { HRU_SLP } \\
\text { (.hru) }\end{array}$ & $\begin{array}{l}\text { Average slope (m / } \\
\mathrm{m})\end{array}$ & $0,037046-0,338990$ & 0,179337 \\
\hline 6 & $\begin{array}{l}\text { USLE_P } \\
\text { (.mgt) }\end{array}$ & $\begin{array}{l}\text { USLE Equation } \\
\text { Support Practice } \\
\text { Factor }\end{array}$ & $0,732921-1,142015$ & 1,106731 \\
\hline
\end{tabular}

The Validation Process was conducted in 2013-2015. Validation is done using a range of calibration parameter values with observational discharge data for 2013-2015. Based on 
the results of validation, the coefficient value of NS (Nash-Sutcliffe) is $0.62, \mathrm{R}^{2}$ value is 0.62 . Based on the statistical test values generated the SWAT model validation can be used to predict the observation discharge of Way Seputih Watershed.

\subsection{Sediment Yield Assessment and Prediction}

The Way Seputih watershed is divided into 11 sub-watersheds based on delineation watershed in the SWAT analysis. Based on the results of the SWAT set up in the previous discussion, sediment results were obtained for each Sub-watershed (Figure 7). Figure 7 shows the sediment results by category based on sediment analysis per Sub-Watershed. 4 classes were simulated into 6 years, 2010-2015. The average sediment yield in each subwatershed is 117.027 tons/ha. Most $43 \%$ of the sediment comes from SubDAS No. 11, which is the most upstream. This is by research conducted by [5], that forest land has been converted into settlements by $11.26 \%$ in $2010-2015$.

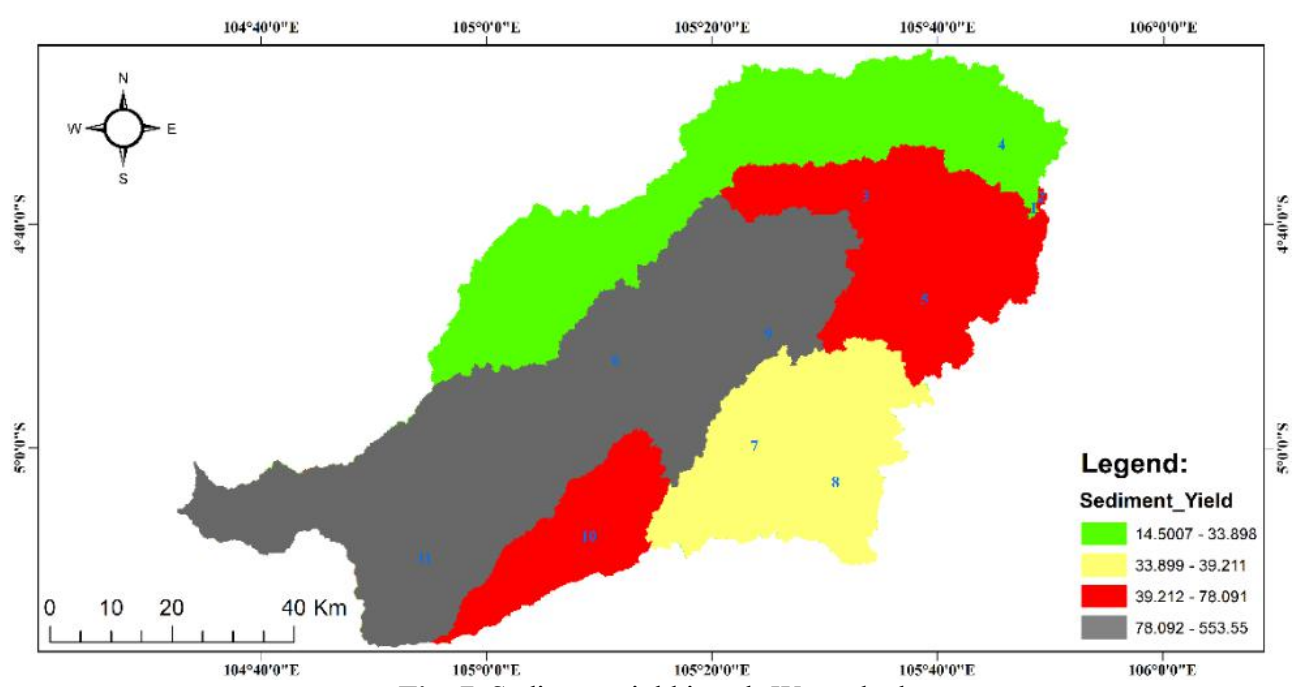

Fig. 7. Sediment yield in sub-Watershed

The highest sediment prediction is generally in the main river basin. The threat to the potential for sediment flows from Sub-Watershed number 11 downstream is very high. Even though the downstream watershed is a water transportation route. If sediment deposits accumulate, the potential for water supply lines to be cut off is even greater. Besides, settlements downstream of the river will also be affected by flooding in the rainy season. The inability of rivers to accommodate discharge due to silting is a major factor in the occurrence of floods.

Continuous application of sediment control is required. The lack of technology in the Way Seputih watershed is also a factor in influencing the performance of sediment management. The big impact arises if the sedimentation rate is high, which can reduce the hydrology of the watershed.

\section{Conclusion}

The results of calibration and validation show the suitability of the model flow with AWLR. This is evidenced by statistical tests with NS (Nash-Sutcliffe) coefficient value is $0.58, \mathrm{R}^{2}$ value is 0.69 . Changes in land use that are predominant occur on increasingly declining agricultural land. The change was converted to a settlement. The impact caused 
by these changes will potentially cause an increase in erosion on the surface water flow. Therefore it is necessary to create integrated management of watershed management.

The results of this model are well based on the calibration and validation processes. This prediction will help see the sedimentation pressure in the Way Seputih watershed. Reduced forest land must be reduced to reduce its impact on the carrying capacity of the watershed environment. Therefore, good sediment management must be a priority. Apart from technological factors that are not good or not available yet. In 6 years, the settlement will increase by $1.68 \mathrm{Km}^{2}$, so this will increase constantly or dynamically if the forest area continues to decrease. One effort that can be done is to organize land use/cover by implementing related policies.

\section{Suggestions}

The government needs to make regulations that form the basis of land use/cover in an area. These regulations should be binding. Lately, irreversible land conversion has often taken place. Therefore, there is a need for binding regulations.

\section{References}

1. K. Welde, B. Gebremariam, Effect of land use land cover dynamics on hydrological response of watershed: Case study of Tekeze Dam watershed, Northern Ethiopia. ISWCR 5, (2017)

2. W. Pratama, S.B. Yuwono, Analisis Perubahan Penggunaan Lahan Terhadap Karakteristik Hidrologi Di Das Bulok. J. Sylva Lestari 4, 3 (2016)

3. R.M.Z. Fauzi, Maryono, Kajian Erosi Dan Hasil Sedimen Untuk Konservasi Lahan DAS Kreo Hulu. J. Pembangunan Wilayah dan Kota 12, 4 (2016)

4. M. Amin, Londuse Planning for Way Seputih Waterslted at Central Lampung by Water Management Model. J. Manusia dan Lingkungan 15, 3 (2008)

5. D.R. Romlah, S.B. Yuwono, R. Hilmanto, and I.S. Banuwa, Pengaruh Perubahan Tutupan Hutan Terhadap Debit Way Seputih Hulu. J. Hutan Tropis 6, 2 (2018)

6. S.C. Brown, V.L. Vesace, R.E. Lester, and M.T. Walter, Assessing the impact of drought and forestry on streamflows in south-eastern Australia using a physically based hydrological model. Environ. Earth Sci. 74, (2015)

7. D.N. Khoi, T. Suetsugi, Impact of climate and land-use changes on hydrological processes and sediment yield - a case study of the Be River catchment, Vietnam. Hydro. Sci. Journal 59, 5 (2014)

8. A.G. Jeffrey, M.N. Daniel, G.P. Walter, A.C. Karim, W.M. James, S. Saghavan, S. Chinnasamay, H.R. Daren, v.G. Ann, v.L.W. Michael, N. Kannan, J.M. Kumar, SWAT: Model use, calibration, and validation. ASABE 55, 4 (2012b)

9. W. Sudjarit, S. Pukngam, N. Tangtham, Application of SWAT model for assessing effect on main functions of watershed ecosystem in Headwater, Thailand. IAEES 5, 2 (2015) 
10. S. L. Neitsch, J. G. Arnold, J. R. Kiniry, and J. R. Williams, Soil and WaterAssessment Tool. Texas: Texas AgriLife Reasearch, 647 (2009).

11. M.K. Shrestha, F. Recknagel, J. Frizenschaf, and W. Meyer, Future climate and land uses effects on flow and nutrient loads of a Mediterranean catchment in South Australia. Science of the Total Environment 590-591, (2017)

12. H. Koo, M. Chen, A. J. Jakeman, and F. Zhang, A global sensitivity analysis approach for identifying critical sources of uncertainty in non-identifiable, spatially distributed environmental models: A holistic analysis applied to SWAT for input datasets and model parameters. Environ. Model. Softw. 127, (2020)

13. V. T. Nguyen, J. Dietrich, and B. Uniyal, Modeling interbasin groundwater flow in karst areas: Model development, application, and calibration strategy. Environ. Model. Softw. 124, (2020) 
14. H. Zhang et al., Rapid consolidation characteristics of Yellow River-derived sediment: Geotechnical characterization and its implications for the deltaic geomorphic evolution. Eng. Geol. 270, (2020)

15. K. C. Abbaspour et al., Modelling hydrology and water quality in the pre-alpine/alpine Thur watershed using SWAT. J. Hydrol. 333, (2007)

16. J. Yang, P. Reichert, K. C. Abbaspour, J. Xia, and H. Yang, Comparing uncertainty analysis techniques for a SWAT application to the Chaohe Basin in China, J. Hydrol. 358, (2008)

17. M. P. Thavhana, M. J. Savage, and M. E. Moeletsi, SWAT model uncertainty analysis, calibration and validation for runoff simulation in the Luvuvhu River catchment, South Africa. Phys. Chem. Earth, 105, (2018)

18. H. Zhang, B. Wang, D. L. Liu, M. Zhang, L. M. Leslie, and Q. Yu, Using an improved SWAT model to simulate hydrological responses to land use change: A case study of a catchment in tropical Australia, J. Hydrol. 585, (2020)

19. A. M. Le and N. G. Pricope, Increasing the accuracy of runoffand streamflow simulation in the Nzoia Basin, Western Kenya, through the incorporation of satellitederived CHIRPS data. Water 9, 114 (2017) 